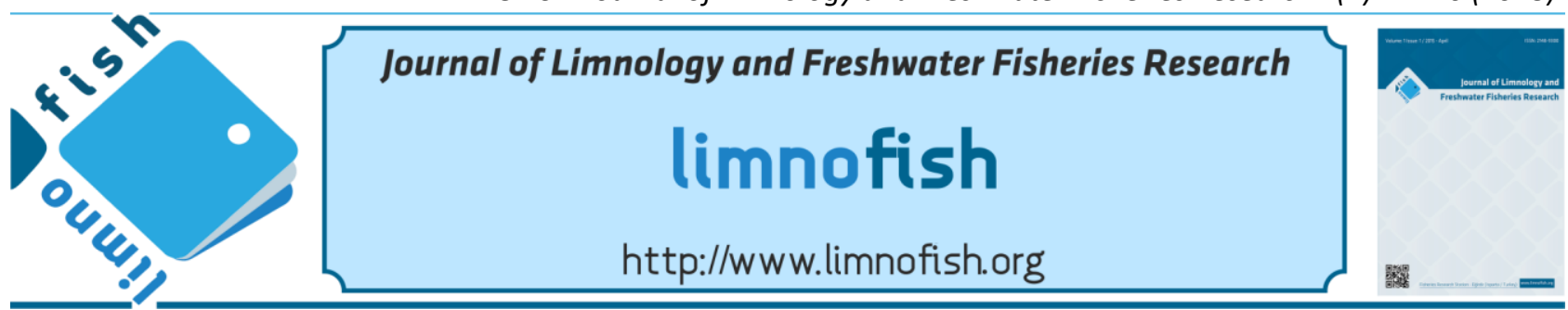

\title{
Intestine Villi Morphology of Black Sea Trout (Salmo labrax Pallas, 1814)
}

\author{
Osman Tolga ÖZEL ${ }^{* * i D}$, İsa COŞKUN ${ }^{2}$ iD, Eyüp ÇAKMAK ${ }^{1}$ iD \\ ${ }^{1}$ Central Fisheries Research Institute, 61250, Trabzon, Turkey \\ ${ }^{2}$ Ahi Evran University, Faculty of Agriculture, Department of Animal Science, 40200, Kırşehir, Turkey
}

\section{A B STRACT}

This study was conducted to determine the effect of age, sex and weight on the middle intestine villi morphology of fifth-generation Black Sea trout (Salmo labrax Pallas, 1814). The fish were kept in the freshwater ponds (June-October) and marine cages (November-May) to provide the life cycle of species. Intestine tissue samples were taken during period when fish were kept in marine cages. Our results showed that, middle intestine villi morphology changed depending on fish age (I, II, III, IV and V years old) and different live weight (low weighted and high weighted) of similar ages (16 months old). The lowest intestine villi development was obtained in I years old fish. This was followed by II years old fish. The highest intestine villi development was obtained in III years old fish. Besides, intestine villi development of high weighted fish was higher than those of low weighted fish. However, it was found that middle intestine villi morphology did not changed depending on sex.

Keywords: Trout, age, sex, weight, histology

\section{ARTICLE INFO}

\section{SHORT COMMUNICATION}

Received : : 13.12 .2017

Revised : :05.03.2018

Accepted :08.03.2018

Published : 27.04.2018

DOI:10.17216/LimnoFish.365434

* CORRESPONDING AUTHOR

osmantolga.ozel@tarim.gov.tr Tel : +90 4623411053

\section{Karadeniz Alabalığı (Salmo labrax Pallas, 1814)'nın Bağırsak Villi Morfolojisi}

Öz: Bu çalışma, 5. (F5) nesil Karadeniz alabalığı (Salmo labrax Pallas, 1814)'nın bağırsak villi morfolojisi üzerine yaş, cinsiyet ve ağırlığın etkisini belirlemek için yapılmıştır. Türün doğal yaşam döngüsünü sağlamak için, balıklar tatlısu havuzlarında (Haziran-Ekim) ve deniz kafeslerinde (Kasım-Mayıs) tutulmuştur. Bağırsak doku örnekleri, balıkların deniz kafeslerinde tutulduğu dönemde alınmıştır. Çalışmada elde edilen sonuçlara göre, orta bağırsak villi morfolojisi balığın yaşına (I, II, III, IV ve V yaş) ve aynı yaştaki balığın (16 aylık yaş) farklı canlı ağırlığına (düşük ve yüksek ağırlıklı) bağlı olarak değişmiştir. En düşük bağırsak villi gelişimi I yaşı balıklarda görülmüş, bunu II yaşlı balıklar takip etmiştir. En yüksek bağırsak villi gelişimi ise III yaşlı balıklarda görülmüş̧ür. Ayrıca yüksek ağırlığa sahip balıkların bağırsak villi gelişimi düşük ağırlıklaki balıklardan daha yüksek bulunmuştur. Ancak orta bağırsak villi morfolojisi üzerine cinsiyetin etkisinin olmadığı tespit edilmiştir.

Anahtar kelimeler: Alabalık, yaş, cinsiyet, ağırlık, histoloji

How To Cite

Özel OT, Coşkun İ, Çakmak E. 2018. Intestine Villi Morphology of Black Sea Trout (Salmo labrax Pallas, 1814) LimnoFish. 4(1): 42-46. doi: 10.17216/LimnoFish.365434

\section{Introduction}

Black Sea trout as a subspecies of the brown trout is distributed at the Eastern Black Sea. This is an endemic species for Turkey. This species has three different ecotypes in the natural environment: sea ecotype, stream ecotype and lake ecotype. These ecotypes have great variations in terms of color (Tabak et al. 2002). In Black Sea condition, Black Sea trout are grown in freshwater ponds until smolt stage, and then smoltified in seawater when they reach nearly $12 \mathrm{~cm}$ of length and $15 \mathrm{~g}$ of weight. In marine cages, fish are grown during the periods
(November-May) allowed by the water temperature. At the end of the season, when the temperature of sea water reached critical value $\left(18{ }^{\circ} \mathrm{C}\right)$ for Black Sea trout aquaculture, the fish are harvested or transferred to freswater ponds for brood maintenance (SUMAE 2010).

The digestive canal of teleost fish is divided into headgut, foregut, midgut and hindgut. The headgut is composed of the mouth and gill cavities. The foregut is comprised of the esophagus, stomach and pylorus. The midgut contains the intestine and a variable number of pyloric caecae, and is the greatest part of the gastrointestinal tract. The hindgut begins by an 
increase in diameter of the gastrointestinal tract and ends with the anus (Floris 2010). The gastrointestinal tract are responsible to storing food and water, processing ingested food and water and absorbing digested food and water, and excreting wastes (Jutfelt 2006). Intestine has very important roles such as to complete the digestive process started in the stomach, and to absorb the nutrients from ingested food (Nasruddin et al. 2014). Thus, histologically examination of the digestive system (especially intestine) is quite important. With this way, the knowledge related to nutritional status of fish is can be obtained (Chowdhary et al. 2013; Yadav et al. 2014).

The histological features of intestine may be influenced by abiotic and biotic factors (Khojasteh 2012) such as species and feed (Raskovic et al. 2011), feeding habit, age, and body shape (Cao et al. 2011). Intestine of fish is composed of mucosa, submucosa, muscularis and serosa layers (Mokhtar et al. 2015). Mucosa layer is composed of epithelium, lamina propria and muscularis mucosa (Mumford et al. 2007). Intestine villi is located in enterocyte cells of epithelium.

Intestine villi play an important role both in the absorption of nutrients and in the pumping of absorbed nutrients into the blood or lymph (Karabulut 1991). Moreover, knowledge to be obtained about the intestine villi will contribute on the nutritional studies to be carried out. Thus, the evaluation of intestine villi morphology of Black Sea trout is aimed in this study.

\section{Material and Methods \\ Experimental Design}

The study was conducted as three groups at Central Fisheries Research Institute (Trabzon,Turkey): Age (I, II, III, IV and V years old), sex (adult fish; between III and IV years old) and different weight of similar ages (16 months old). In the study, fifth-generation Black Sea trout were used. For age and sex studies, the fish were kept in the freshwater ponds $\left(0.5-18.5^{\circ} \mathrm{C}\right)$ fed by stream between May-November 2016. After that, the fish were transferred to the sea cages (6.9-7.6 $\left.{ }^{\circ} \mathrm{C}\right)$ in November 2016. Fish were selected as five groups (I, II, III, IV and V years old) according to their age. For different weight study, the fish (from larvae to smolt stage) kept in the freshwater ponds $\left(10.1-12.5^{\circ} \mathrm{C}\right)$ fed by spring water between January-November 2016. After that, the fish $(18.63 \pm 3.84 \mathrm{~g})$ were transferred in seawater $\left(6.9-16.6{ }^{\circ} \mathrm{C}\right)$ in November 2016 where they were kept for 6 months. Fish, 16 months old, were selected as two groups according to their live weight: Low weighted group $(L W)$ and high weighted group $(H W)$. Fish were fed at ad-libitum feeding level during experiment. Water temperature was recorded daily. Seawater salinity was recorded as $0.18 \%$.

\section{Intestine Sampling}

Intestine samplings for age and sex studies were taken in January 2017 in seawater $\left(7.6{ }^{\circ} \mathrm{C}\right)$, while sampling for different weight study was taken in May 2017 in seawater $\left(16.6{ }^{\circ} \mathrm{C}\right)$. Twenty of fish from each group for every three experiments, middle intestine tissues were taken, and analyzed by placing the samples into $10 \%$ formalin then into the tissue cassettes for dehydration process and embedded in paraffin blocks, and subsequently cut 5- $\mu \mathrm{m}$ thickness and placed on a slide. Each sample was stained with hematoxylin and eosin. After staining, villi length $(V L)$, villi width $(V W)$ and villi length to villi width $(V L / V W)$ were evaluated by using an image processing and analysis system (ZEN 2012 SP2) (Xu et al. 2003).

\section{Statistical Analysis}

Data of age were analyzed by one-way analysis of variance. Differences between means were compared using Duncan's multiple range test. Data of sex and different weight were analyzed by independent samples t test. Statistical analyses were computed using SPSS 15.0.

\section{Results}

There was significantly difference between groups in terms of both fish weight and middle intestine villi morphology $(\mathrm{P}<0.05)$. Weights of the I, II, III, IV and V years old fish were recorded as $80.83 \pm 9.09 \mathrm{~g}, 819.82 \pm 189.59 \mathrm{~g}$, $2548.5 \pm 681.14 \mathrm{~g}, \quad 3064.65 \pm 979.33 \mathrm{~g}$ and $3598.88 \pm 928.85 \mathrm{~g}$ respectively. The lowest $V L, V W$ and $V L / V W$ were obtained in I years old fish. This was followed by II years old fish. The highest $V L$ and $V W$ were obtained in III years old fish. $V L$ of the IV and $\mathrm{V}$ years old fish were similar to each other, respectively. Also, $V W$ of the II, IV and $\mathrm{V}$ years old fish were similar to each other, respectively. Furthermore, $V L / V W$ of the 3,4 and 5 years old fish were similar to each other, respectively (Table 1).

There wasn't significantly difference between groups (female and male) in terms of both fish weight and middle intestine villi morphology $(\mathrm{P}>0.05)$. Weights of female and male fish were recorded as $2763.44 \pm 1111.39 \mathrm{~g}$ and $2826.81 \pm 711.77 \mathrm{~g}$, respectively. $V L, V W$ and $V L / V W$ of male and female fish were $1100.86 \pm 145.92 \mu \mathrm{m}$ and $1090.72 \pm 107.98$ $\mu \mathrm{m}, 158.94 \pm 38.22 \mu \mathrm{m}$ and $168.44 \pm 41.65 \mu \mathrm{m}$, $7.38 \pm 2.22$ and $6.86 \pm 1.81$, respectively (Table 2 ). 
Table 1. Age-dependent middle intestine villi morphology of Black Sea trout.

\begin{tabular}{lcccc}
\hline Age & Weight $(\mathrm{g})$ & VL $(\mu \mathrm{m})$ & VW $(\mu \mathrm{m})$ & VL/VW \\
\hline I & $80.83 \pm 9.09^{\mathrm{e}}$ & $315.39 \pm 92.62^{\mathrm{d}}$ & $65.18 \pm 13.40^{\mathrm{c}}$ & $4.94 \pm 1.42^{\mathrm{c}}$ \\
II & $819.82 \pm 189.59^{\mathrm{d}}$ & $713.98 \pm 73.44^{\mathrm{c}}$ & $147.06 \pm 35.54^{\mathrm{b}}$ & $5.20 \pm 1.60^{\mathrm{b}}$ \\
III & $2548.50 \pm 681.14^{\mathrm{c}}$ & $1160.52 \pm 90.74^{\mathrm{a}}$ & $174.76 \pm 36.56^{\mathrm{a}}$ & $6.92 \pm 1.51^{\mathrm{a}}$ \\
IV & $3064.65 \pm 979.33^{\mathrm{b}}$ & $1092.50 \pm 121.29^{\mathrm{b}}$ & $152.64 \pm 47.89^{\mathrm{b}}$ & $7.80 \pm 2.39^{\mathrm{a}}$ \\
V & $3598.88 \pm 928.85^{\mathrm{a}}$ & $1046.11 \pm 140.00^{\mathrm{b}}$ & $157.59 \pm 33.07^{\mathrm{b}}$ & $6.99 \pm 2.06^{\mathrm{a}}$ \\
\hline
\end{tabular}

Means with different superscript letters in a column are significantly different $(\mathrm{P}<0.05)$

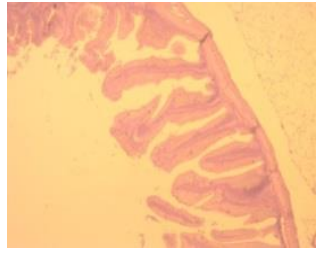

(a)

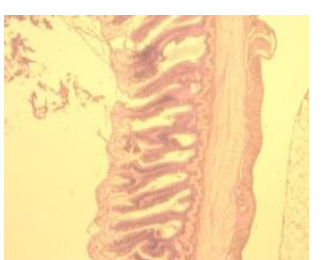

(b)

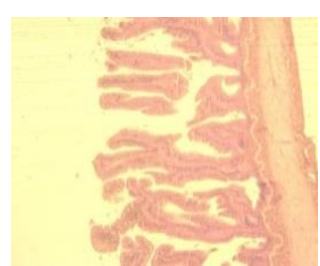

(c)

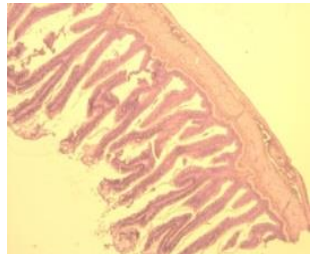

(d)

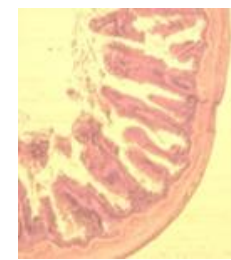

(e)

Figure 1.Middle intestine villi histology of Black Sea trout. One to five years old: (a,I; b,II; c,III; d,IV; e,V years old) (4x, H\&E).

Table 2. Sex-dependent middle intestine villi morphology of adult Black Sea trout.

\begin{tabular}{lcccc}
\hline Sex & Weight $(\mathrm{g})$ & VL $(\mu \mathrm{m})$ & VW $(\mu \mathrm{m})$ & VL/VW \\
\hline Female & $2763.44 \pm 1111.39$ & $1090.72 \pm 107.98$ & $168.44 \pm 41.65$ & $6.86 \pm 1.81$ \\
Male & $2826.81 \pm 711.77$ & $1100.86 \pm 145.92$ & $158.94 \pm 38.22$ & $7.38 \pm 2.22$ \\
\hline
\end{tabular}

There was significantly difference between groups ( $L W$ and $H W$ ) in terms of both fish weight and middle intestine villi morphology ( $V L, V W$ and $V L / V W)$. Weights of low weighted fish and high weighted fish were recorded as $151.86 \pm 12.65 \mathrm{~g}$ and $372.83 \pm 15.92 \mathrm{~g}$, respectively. While $V L, V W$ and $V L / V W$ of low weighted group were $473.38 \pm 76.07 \mu \mathrm{m}$, $114.18 \pm 22.36 \mu \mathrm{m}$ and $4.29 \pm 1.05, \mathrm{VL}, \mathrm{VW}$ and VL/VW of high weighted group were $605.96 \pm 97.54$ $\mu \mathrm{m}, 130.28 \pm 22.76 \mu \mathrm{m}$ and $4.78 \pm 1.10$, respectively (Table 3).

Table 3. Different weight-depend middle intestine villi morphology of Black Sea trout.

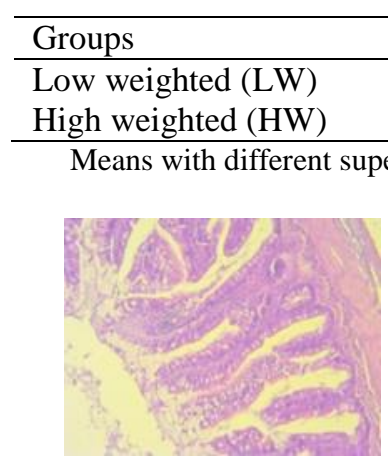

(a)

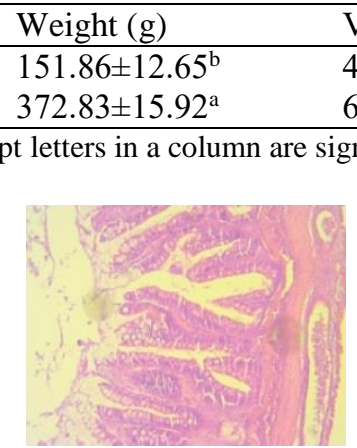

(b)

$\begin{array}{lc}\text { VL }(\mu \mathrm{m}) & \mathrm{VW}(\mu \mathrm{m} \\ 473.38 \pm 76.07^{\mathrm{b}} & 114.18 \\ 605.96 \pm 97.54^{\mathrm{a}} & 130.28 \\ & \\ & \\ & \\ & \end{array}$

(c)

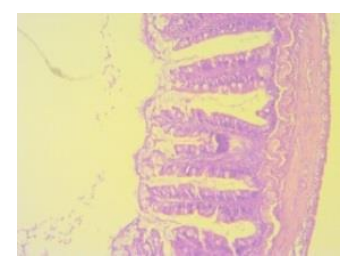

(d)

Figure 2. Middle intestine villi histology of Black Sea trout. a-b: high weighted, c-d: low weighted. (4x, H\&E).

\section{Discussion}

Growth is expressed as gradually the improvement in a living organism depending on time. In fish, growth varies depending on feed consumption and quality, stocking density, sex, age, genetic variance, water chemistry, temperature, photoperiod and oxygen level (Lugert et al. 2000). Age and growth are in a close relationship (Bhatt and Jahan 2015). Growth rate can be affected fish size, and generally tends to decrease with the increase in the size of organisms (Jonsson and Jonsson 2007). Our study demonstrated that as fish get older, its body weight increased, but growth rate were not. Fish growth rate was increasingly increased from I to III years old, but were diminished after III years old. This may be related to the completion of some physiological developments such as sexual maturity of this species. Stream and sea ecotypes of Black Sea 
trout reach the sexual maturity in 22 and 34 months old, respectively (Unpublished). According to Anonymous (2012), early sexual maturation reduces growth rate in farmed Atlantic Salmon. Smilarly, Jonsson and Jonsson (2007) stated that body size of Atlantic salmon changes continuously among populations, and this seems to be related to growth rate and sexual maturity age, as late maturing fish tend to be more fast growing than mature ones. Similar to the growth rate, middle intestine villi morphology also changed depending on age of fish in our study. Villi length and width were increasingly increased from I to III years old, but were diminished after III years old. The intestine villi structure developed until the fish completed sexual maturity, but then showed tend to weaken. This may arise from growth rate of fish species. Michel-Parra et al (2007) found that jejenum intestine villi length changed depending on age $(10,20,30,40$ and 60 days) in Tilapia (Orechromis aureus). It is clear fact that, studies carried out on this subject are insufficient.

Black Sea trout is an opportunistic ecotype (Tabak et al. 2002) and there is competition among their individuals in terms of nutrition. This can lead to different weight in the fish in the similar ages. In this study, although the fish were kept same environmental conditions and were fed with the same feed, fish with different weights were observed. This is reflected in the middle intestine villi morphology. Coskun and Bat (2015) found that the difference in the live weights of broiler chickens kept under the same environmental factors and fed on the same feed had no significant effect on histomorphological parameters. This may arise from the weight averages of broiler chickens are close to each other. Discussion was made on other monogastric species due to lack of knowledge with fish species.

We may say that middle intestine villi development ( $V L, V W$ and $V L / V W$ ) were proportional to the growth rate, and increased depending on live weight gain, and also changed depending on age. For better understanding of intestine villi morphology of this species, other sections (proximal and distal) of the intestine should be examined, and villi feeding studies should be carried out. In addition, special feeding (feed additives etc.) programs can be applied to improve the intestine villi morphology of low weighted fish.

\section{Acknowledgements}

This research was done as a preliminary study for the project named "Possibilities of using some phytobiotic added diets in feeding of Black Sea trout (Salmo trutta labrax Pallas, 1814)" supported by General Directorate of Agricultural Research and Policies. Part of the research was presented as oral and poster presentations at the International Symposium on Limnology and Freshwater Fisheries.

\section{References}

Anonymous 2012. The Effect of photoperiod on growth and maturation of Atlantic salmon (Salmo salar) in the bay of fundy. Aquaculture science branch fisheries and oceans Canada. Issue 14.

Bhatt BJ, Jahan N. 2015. Determination of age and growth rate of fresh water fish Labeo rohita (Ham. 1822) by using cycloid scales. Int J Pure App Biosci. 3 (3): 189200.

Cao XJ, Wang WM, Song F. 2011. Anatomical and Histological Characteristics of the Intestine of the Topmouth Culter (Culter alburnus). Anat Histol Embryol. 40(4):292-298. doi: 10.1111/j.1439-0264.2011.01069.x

Chowdhary S, Srivastava PP, Jena J, Yadav AK, Dayal R, Mishra S, Srivastava M. 2013. Histological studies of the intestine in threatened Asian catfish (Clarias batrachus) fingerlings fed with animal or plant origin protein blended with glucosamine. Int J Fish Aquat Stu. 1(2):50-55.

Coskun I, Bat G. 2015. Etlik piliçlerin ileum histolojisi ve goblet hücre sayısı üzerine farklı kesim canlı ağırlığının etkisi. Tavukçuluk Araştırma Dergisi 13 (2): 1-4. [in Turkish]

Floris R. 2010. Microbial ecology of the intestinal tract of gilthead sea bream (Sparus aurata Linnaeus, 1758). [PhD Thesis]. University of Sassari. $133 \mathrm{p}$.

Jonsson N, Jonsson B. 2007. Sea growth, smolt age and age at sexual maturation in Atlantic salmon. J Fish Biol. 71 (1): 245-252.

doi:10.1111/j.1095-8649.2007.01488.x.

Jutfelt F. 2006. The Intestinal epithelium of Salmonids. [PhD Thesis]. University of Gothenborg. 73 p.

Karabulut A. 1991. Hayvan besleme fizyolojisi ve metabolizması ders notu. Uludağ Ünivesitesi, Ziraat Fakültesi, Bursa, Türkiye. [in Turkish]

Khojasteh SMB. 2012. The morphology of the post-gastric alimentary canal in teleost fishes: a brief review. International Journal of Aquatic Science. 3 (2): 71-88.

Lugert V, Thaller G, Tetens J, Schulz C, Krieter J. 2000. A review on fish growth calculation: multiple functions infish production and their specific application. Rev Aquacult. 8 (1): 30-42. doi: 10.1111/raq.12071

Michel-Parra JG, Hernadez JRO, Garcia IJR, Valdez ODM. 2007. Effect of protein level on alevins growth and intestinal villi development of Tilapia (Orechromis aureus). J Fisheries Int. 2 (3): 211-213.

Mokhtar DM, Abd-Elhafez EA, Hassan AH. 2015 Light and scanning electron microscopic studies on the intestine of Grass carp (Ctenopharyngodon idella): IAnterior intestine. J Aquac Res Development 6(11): 374.

doi:10.4172/2155-9546.1000374

Mumford S, Heidel J, Smith C, Morrison, J, MacConnell B, Blazer V. 2007. Fish histology and histopathology. [cited from:22/04/2017] Available from: https://training.fws.gov/resources/course-resources /fish-histology/Fish-Histology_Manual_v4.pdf 
Nasruddin NS, Azmai MNA, Ismail A, Saad MZ, Daud HM, Zulkifli SZ. 2014. Histological features of the gastrointestinal tract of wild Indonesian shortfin Eel, Anguilla bicolor bicolor (McClelland, 1844), captured in peninsular Malaysia. Sci World J. Article ID 312670,8 pages. doi:10.1155/2014/312670

Raskovic BS, Stankovic M.B, Markovic ZZ, Poleksic VD. 2011. Histological methods in the assessment of different feed effects on liver and intestine of fish. J Agricult Sci. 56 (1): 87-100. doi: 10.2298/JAS1101087R

SUMAE. 2010. Karadeniz alabalı̆̆ (Salmo trutta labrax) yetiştiriciliği el kitabı, E. Çakmak, M. Aksungur (Ed.), $\mathrm{Su}$ Ürünleri Merkez Araştırma Enstitüsü Müdürlüğü, Yayın No: 2010-2 Trabzon, 58 s. [in Turkish]
Tabak I, Aksungur M, Zengin M, Yılmaz C, Aksungur N, Alkan A, Zengin B, Misir DS. 2002. Karadeniz alabalığı (Salmo trutta labrax, Pallas 1811)'nın biyoteknolojik özelliklerinin tespiti ve kültüre alınabilirliğinin araştırılması projesi, TAGEM/HAYSUD/98/12/01/2007. [in Turkish]

$\mathrm{Xu} \mathrm{ZR}, \mathrm{Hu} \mathrm{CH}$, Xia MS, Zhan XA, Wang MQ. 2003. Effects of dietary fructooligosaccharide on digestive enzyme activities, intestinal microflora and morphology of male broilers. Poult Sci. 82 (6): 10301036.

doi: $10.1093 / \mathrm{ps} / 82.6 .1030$

Yadav AK, Srivastava PP, Chowdhary S, Lakra WS, Shrivastava P, Dayal R. 2014. Histological alterations in the intestine of threatened Asian catfish, Clarias batrachus fed with different types of fats through semipurified diets. Adv Appl Sci Res. 5(2):35-41. 